\title{
KRYZYS, ROZPAD I ODRODZENIE I RZECZYPOSPOLITEJ W OKRESIE II WOJNY PÓłNOCNEJ (1655-1660)
}

\begin{abstract}
Abstrakt: Rzeczpospolita Obojga Narodów przeszła w połowie XVII stulecia głęboki wielostronny kryzys: demograficzny, gospodarczy, polityczny i militarny. Doprowadził on do rozpadu państwa w 1655 r., a następnie do próby jego podziału w grudniu 1656, określanej często jako próba pierwszego rozbioru Polski. Przełamanie kryzysu umożliwił wciąż duży potencjał państwa i przezwyciężenie załamania moralnego społeczeństwa oraz brak zgody Tatarów, Moskwy, Habsburgów i Danii na rozbiór Rzeczypospolitej.
\end{abstract}

Słowa kluczowe: Rzeczpospolita Obojga Narodów, potop szwedzki, kryzys, traktat w Radnot, wojna.
Abstract: In the mid-seventeenth century, the Polish-Lithuanian Commonwealth was hit by a severe and multi-dimensional crisis: demographic, economic, political and military. It led to the collapse of the state in 1655 , and then to the attempt at its division in December 1656, often referred to as an attempt at its first partition. This, however, was prevented by still considerable potential of the state, which made it possible to defuse the crisis and overcome the moral breakdown of society, as well as the lack of consent to the partition by the Tatars, Moscow, the Habsburgs, and Denmark.

Keywords: Polish-Lithuanian Commonwealth, Swedish Deluge, crisis, Treaty of Radnot, war.

W dniu 6 grudnia 1656 r. w Radnot w księstwie siedmiogrodzkim zawarto traktat, który miał położyć kres istnieniu państwa polsko-litewskiego, choć pewna, niewielka zresztą część Rzeczypospolitej zachowała nazwę Królestwa Polskiego. Przypomnijmy zatem, że jego mocą król szwedzki Karol X Gustaw otrzymał całe Prusy Królewskie z wyjątkiem Warmii, która miała wejść w skład państwa brandenburskiego. Prócz tego szwedzkimi stawały się Kujawy, większa część Mazowsza, Żmudź, cztery powiaty litewskie: kowieński, upicki, brasławski i wołkowyski, Inflanty polskie 
oraz Kurlandia. Drugi z kontrahentów, elektor brandenburski Fryderyk Wilhelm, dostawał oprócz Warmii województwa: poznańskie, kaliskie, łęczyckie i sieradzkie z ziemią wieluńską. Książę siedmiogrodzki Jerzy II Rakoczy, pretendujący do tytułu króla polskiego, otrzymywał mniejszą część Mazowsza, województwa: krakowskie, sandomierskie, lubelskie, podlaskie i część województwa ruskiego, gdzie miała przebiegać granica z państwem Bohdana Chmielnickiego. Hetman zaporoski zatrzymywał większą część ziem ruskich Korony z Wołyniem, Podolem i całą Ukrainą. Wysuwał też pretensje do tej części ziem białoruskich, które opanowała Moskwa. Wreszcie województwo nowogrodzkie stawało się księstwem dziedzicznym Bogusława Radziwiłła.

Pierwszy plan rozbioru Polski autorstwa króla szwedzkiego Karola X Gustawa miał jednak istotne wady. Po pierwsze, w sposób jednorazowy, a przez to gwałtowny likwidował organizm państwowy liczący sobie około 900 tys. $\mathrm{km}^{2}$. Po drugie, nie tylko nie był uzgodniony z pozostałymi sąsiadami Rzeczypospolitej, ale nawet nie był z nimi konsultowany (Habsburgowie, Moskwa, Turcja). Po trzecie wreszcie, czynił z księcia siedmiogrodzkiego i Bohdana Chmielnickiego - osób mających status lenników tureckich i moskiewskich - suwerennych władców. Istniał jeszcze jeden czynnik, który nie został w dostateczny sposób doceniony przez szwedzkiego monarchę i jego kontrahentów, mianowicie siła Rzeczypospolitej Obojga Narodów i zdolność jej mieszkańców, w tym także elit, do ratowania bytu państwowego ojczyzny.

Zgodzić się można w pełni ze zdaniem Mariusza Stangreciuka, że traktat w Radnot stanowił kulminację procesów polityczno-wojskowych zapoczątkowanych w $1648 \mathrm{r}^{1}$ Przyjrzyjmy się zatem wydarzeniom, które do takiej próby wymazania Polski z mapy świata doprowadziły.

1.

Powstanie kozackie pod wodzą Bohdana Chmielnickiego wybuchło w najgorszym dla państwa polsko-litewskiego momencie, gdyż zbiegło się ze śmiercią Władysława IV (20 V 1648). Nie chodzi tylko o to, że mogło się rozprzestrzeniać w okresie interregnum, a więc w czasie najbardziej niebezpiecznym dla egzystencji Rzeczypospolitej, ale również o to, że zmarły monarcha był niekwestionowanym autorytetem dla Kozaków

${ }^{1}$ M. Stangreciuk, Traktat $w$ Radnot (6 grudnia 1656) jako pierwsza próba rozbioru ziem Rzeczypospolitej. Przyczyny, realizacja, w: Z dziejów stosunków Rzeczypospolitej Obojga Narodów ze Szwecja w XVII wieku, red. M. Nagielski, Warszawa 2007, s. 216. 
zaporoskich. Jeśli weźmiemy dodatkowo pod uwagę, że zabrakło najbardziej podówczas zdolnego wodza, to tragizm sytuacji stanie się bardziej wyrazisty. Władysław IV właśnie ze względu na swoje wybitne zdolności wojskowe nie przywiązywał wielkiej wagi do nominacji na urzędy hetmanów koronnych. Przez cały rok 1648 były widoczne negatywne skutki królewskiej polityki nominacyjnej w armii koronnej, a klęski, które były tego następstwem, umożliwiały rozszerzenie się powstania na wszystkie ziemie ruskie Korony, a nawet na Polesie litewskie.

Powstanie Chmielnickiego miało dodatkowo dwa negatywne następstwa dla państwa polsko-litewskiego. Po pierwsze, w związku ze zdradą Kozaków rejestrowych w maju 1648 i ich przejściem na stronę powstańców załamała się istniejąca do tej pory struktura armii koronnej, w której kilka tysięcy kozaków stanowiło istotny komponent. Od tej pory wojsko musiało walczyć z żołnierzami stanowiącymi niegdyś jego część. Po drugie, sukcesy powstańców doprowadziły do radykalizacji ich żądań i w efekcie do rozwoju tendencji separatystycznych wśród Kozaków zaporoskich. Chmielnicki bardzo szybko stał się zwolennikiem utworzenia państwa kozackiego, początkowo luźno związanego z Rzecząpospolitą. Od początku sojusznikiem Kozaków był chanat krymski, zatem czynnik zewnętrzny odgrywał, w różnych zresztą konfiguracjach, znaczną rolę w tej wojnie domowej. Po zwycięstwie pod Korsuniem (25-26 V 1648) hetman zaporoski wysłał poselstwo do księcia siedmiogrodzkiego Jerzego II Rakoczego z propozycją, aby ten ubiegał się o tron polski. Chmielnicki zamierzał do swego planu pozyskać także Janusza Radziwiłła, podówczas hetmana polnego litewskiego i starostę żmudzkiego². Wprawdzie książę siedmiogrodzki wycofał swoją kandydaturę w trakcie elekcji, ale nie zapomniał o życzliwości Kozaków. W połowie lutego 1649 r. poselstwo siedmiogrodzkie zaproponowało w Perejasławiu hetmanowi zaporoskiemu, aby uznał nad sobą zwierzchnictwo Siedmiogrodu. Oferta ta nie odpowiadała jednak w żadnym wypadku ambicjom tworzącego się państwa kozackiego.

Wobec pewnych sukcesów Rzeczypospolitej na polu militarnym w roku 1649, wśród Kozaków doraźnie zwyciężyła koncepcja związku z państwem polsko-litewskim, ale z zachowaniem dużej autonomii Kozaczyzny. Wyrazem tego była ugoda zawarta pod Zborowem (sierpień 1649), w której oferowano Kozakom jako region autonomiczny województwa:

2 Ibidem, s. 216; Т. Чухліб, Конияепияія полівасалітетної підлеглості Б. Хмельницъько20 та українсько-російські взаємовідносини середини XVII cm., w: Україна та Росія. Проблеми політичних і соціокультурних відносин. Збірник наукових прац̧ь, red. В.А. Смолій et al., Київ 2003, s. 172. 
bracławskie, czernihowskie i kijowskie, a rejestr kozacki podniesiono do 40 tys. żołnierzy. Było to więc o wiele więcej niż wynosiły stałe siły zbrojne całego państwa polsko-litewskiego.

Ta pierwsza za panowania Jana Kazimierza próba ułożenia poprawnych stosunków między rodzącym się państwem kozackim - Hetmanatem - a Rzecząpospolitą okazała się nietrwała. Zadecydowały o tym ambicje Chmielnickiego, dążącego w oparciu o księstwa naddunajskie do zbudowania suwerenności kozackiej w tej części Europy. Konfrontacja polsko-kozacka w 1651 r. zakończyła się klęską Kozaków i Tatarów pod Beresteczkiem (28-30 czerwca) i zawarciem nowej ugody pomiędzy stronami, tym razem pod Białą Cerkwią (28 września). Porozumienie to przewidywało jedynie województwo kijowskie jako teren autonomiczny kozacki, a rejestr ograniczono do 20 tys. żołnierzy.

Biała Cerkiew kończyła okres wyraźnej przewagi strony polskiej $\mathrm{w}$ wojnie domowej. Znalazło to swoje odzwierciedlenie w zmianie polityki Moskwy, która zaprzestała przygotowań do interwencji po stronie kozackiej i zajęła pozycję obserwatora. Jak stwierdza Zbigniew Wójcik, car Aleksy zwołał w marcu 1651 r. Sobór Ziemski, który miał podjąć decyzję o przyłączeniu Ukrainy do Moskwy. Nie ogłoszono jednak tego postanowienia i interwencja rosyjska nie nastąpiła. Rzeczpospolitą uratowało wtedy zwycięstwo nad Kozakami pod Beresteczkiem ${ }^{3}$. Z kolei Turcy, którzy już w lecie 1650 r. przyjęli pod swoją protekcję Chmielnickiego, zaoferowali mu tron mołdawski. Po klęsce beresteckiej poparli oni starania starszego syna hetmańskiego, Tymofieja, o rękę córki hospodara Mołdawii Bazylego Lupu. Próba przeciwdziałania ze strony polskiej zakończyła się katastrofą militarną pod Batohem (1-2 VI 1652), w której uległa zagładzie dziesięciotysięczna armia koronna i niemal całe dowództwo $\mathrm{z}$ hetmanem polnym koronnym Marcinem Kalinowskim. Tymofiej Chmielnicki z armią kozacką wkroczył do Suczawy i został zięciem hospodara mołdawskiego. Temu ostatniemu, jak pisał Władysław Konopczyński, „zrobiło się ciasno w Suczawie obok nieokiełznanego zięcia" ". Próbował więc za zgodą Turcji przenieść się na tron wołoski, a potem siedmiogrodzki. Te wszystkie działania spowodowały zawiązanie porozumienia między Siedmiogrodem, Wołoszczyzną i Rzecząpospolitą (marzec-kwiecień 1653) skierowanego przeciw Mołdawii i Kozakom. Sojusz okazał się krótkotrwały, a kontrahenci Jana Kazimierza zadowolili się usunięciem Kozaków z Mołdawii

3 Z. Wójcik, Dzieje Rosji. 1533-1801, Warszawa 1971, s. 138-139. Dodać można, że Bohdan Chmielnicki już 8 czerwca 1648 r. wysłał pismo do cara, prosząc o opiekę i zapraszając na tron polski, ibidem, s. 130.

${ }^{4}$ W. Konopczyński, Dzieje Polski nowożytnej, t. 2: 1648-1795, Warszawa 1936, s. 13. 
(Tymofiej zginął w Suczawie w październiku 1653). Kampania żwaniecka Jana Kazimierza walczącego przeciw Bohdanowi Chmielnickiemu i Tatarom zakończyła się w grudniu ugodą przywracającą warunki ze Zborowa, a więc wyjątkowo niekorzystne dla Rzeczypospolitej.

Nierozstrzygnięcie konfliktu między Rzecząpospolitą a Kozaczyzną w 1653 r. miało fatalne następstwa i niekorzystnie wpłynęło na układ sił, jaki zarysował się, tym razem na dłuższy okres, dla państwa polsko-litewskiego. W październiku tego roku zwołany przez cara Aleksego Sobór Ziemski zadecydował o przyłączeniu Ukrainy do Moskwy. Dodać w tym miejscu należy, że Bohdan Chmielnicki od dłuższego już czasu słał na Kreml prośby o przyjęcie Kozaczyzny w carskie poddaństwo. Sprawa została przypieczętowana w styczniu 1654 r. w Perejasławiu, na tzw. czarnej radzie kozackiej. Rzeczpospolita Obojga Narodów stanęła w obliczu wojny już nie tylko z kozackimi powstańcami, z którymi nie potrafiła sobie zresztą poradzić, ale z potężnym przeciwnikiem, który do wojny z państwem polsko-litewskim przygotowywał się od kilku lat.

Przejście Kozaków zaporoskich pod moskiewskie zwierzchnictwo spowodowało kolejne zmiany w układzie sił w tej części Europy. Wzrost znaczenia Moskwy zaniepokoił Turcję, a przede wszystkim Tatarów krymskich. Rokowania polskiego poselstwa z chanem Islamem Girejem, trwające od kwietnia, doprowadziły w lipcu 1654 r. do zawiązania formalnego sojuszu polsko-tatarskiego, mającego aprobatę Turcji. Można dodać w tym miejscu, że sojusz ten trwał nieprzerwanie aż do roku 1667.

Do momentu rozpoczęcia wojny z Moskwą w 1654 r. sytuacja państwa polsko-litewskiego była trudna, nawet bardzo trudna, ale nie stanowiła zagrożenia dla bytu państwowego. Rozwój ofensywy moskiewskiej w tymże roku okazał się jednak początkiem zdarzeń katastrofalnych dla Rzeczypospolitej Obojga Narodów. Największe straty poniesiono na Litwie. Po trzymiesięcznej obronie padł Smoleńsk. Dorohobuż, Newel, Uświat, Orsza, Połock, Mohylew i Czernihów zostały zajęte właściwie bez walki. Na Ukrainie, dzięki sojuszowi z Tatarami, straty były mniejsze.

Wiosną 1655 r. ruszyła nowa ofensywa moskiewska na Litwie. W lipcu zajęto Mińsk, a w sierpniu niebronione Wilno. Bez mała całe Wielkie Księstwo Litewskie znalazło się pod okupacją moskiewską. W tej niemal beznadziejnej sytuacji w lipcu nastąpiło uderzenie ze strony Szwecji. Nowy król szwedzki Karol X Gustaw złamał w ten sposób rozejm ze Sztumskiej Wsi, który miał trwać aż do $1661 \mathrm{r}$. Rzeczpospolita nie tylko nie była przygotowana do tej nowej wojny, ale i nie brała jej w ogóle pod uwagę. Owszem, prowadzono od kilku lat bezowocne rokowania ze Szwecją na temat warunków pokojowych, ale ataku się nie spodziewano. Świadczy o tym legacja Jana Kazimierza przedstawiona na sejmie (maj-czerwiec 1655). 
Otóż król proponował zwołanie pospolitego ruszenia i wyprawy piechoty łanowej ze wszystkich dóbr. Jak stwierdzał, nie są potrzebne nowe podatki, tylko sprawna egzekucja zaległych ${ }^{5}$. Jan Kazimierz chciał zatem przygotować państwo do odparcia najazdu moskiewskiego. Sejm roku 1655 w czerwcu nie podjął w związku z tym żadnych uchwał wzmacniających obronę Rzeczypospolitej, z wyjątkiem wyrażenia zgody na propozycje przedstawione przez panującego. Tak więc sejm i Rzeczpospolita Obojga Narodów przygotowywali się do wojny z Moskwą, ale nie ze Szwecją. Wyprawione zostało zresztą nowe poselstwo do Szwecji z kolejnymi propozycjami pokojowymi. Obrady zakończono w dniu 20 czerwca, 5 lipca Karol X Gustaw podejmował uroczyście polskie poselstwo w Sztokholmie, które zostało pożegnane 13 lipca, tydzień później zaś król szwedzki wsiadł na okręt wojenny i popłynął na łatwy, jak sądził, podbój Rzeczypospolitej ${ }^{6}$. Charakterystyczne dla szwedzkiej taktyki zwodzenia Polaków było wkroczenie do polskich Inflant już 10 lipca, a więc gdy poselstwo Rzeczypospolitej przebywało jeszcze w Sztokholmie, i rozpoczęcie oblężenia Dyneburga, zdobytego w dziewięć dni później ${ }^{7}$. Formalne wypowiedzenie wojny przez Szwecję nastąpiło w dniu 19 lipca.

Przebieg kampanii wojskowej w wojnie ze Szwecją w 1655 r. nie jest oczywiście przedmiotem naszych rozważań, będziemy się jednak odnosili do niej w miarę potrzeby. Nie ulega wątpliwości, że od lipca do listopada tego roku nastąpiło załamanie się państwowości Rzeczypospolitej Obojga Narodów, co więcej, nastąpił formalny - to znaczy prawny rozpad państwa polsko-litewskiego.

Starsza historiografia podkreślała zwątpienie w możliwość obrony przed Szwedami. Trudno odmówić słuszności temu rozumowaniu, jeśli się weźmie pod uwagę, że tylko w walce z Moskwą i Kozakami utracono większą część terytorium państwa. Wojna z trzecim przeciwnikiem mogła spowodować dalsze, co najmniej równie dotkliwe ubytki terytorialne.

Władysław Czapliński uważał, że wobec groźby wojny ze Szwecją, po dotychczasowych klęskach „znaczna część senatorów uznała za jedyne wyjście dla Polski jak najszybsze wszczęcie układów z groźnym przeciwnikiem". Sądzono przy tym, że Szwedzi za zrzeczenie się tytułu króla

${ }^{5}$ S. Ochman-Staniszewska, Z. Staniszewski, Sejm Rzeczypospolitej za panowania Jana Kazimierza Wazy. Prawo - doktryna - praktyka, t. 1, Wrocław 2000, s. 233-234.

${ }^{6}$ T. Nowak, Geneza agresji szwedzkiej, w: Polska w okresie drugiej wojny północnej 16551660, t. 1: Rozprawy, red. A. Przyboś, K. Lepszy, Warszawa 1957, s. 136.

7 S. Herbst, Wojna obronna 1655-1660, w: Polska w okresie drugiej wojny pótnocnej, t. 2 , s. 62 .

8 W. Czapliński, Rola magnaterii i szlachty w pierwszych latach wojny szwedzkiej, w: Polska w okresie drugiej wojny północnej, t. 1, s. 150. 
Szwecji i Inflant pomogą w walce z Moskwą, nie chcąc dopuścić do jej wzmocnienia kosztem państwa polskiego. Twierdzenia takie podtrzymywał „troskliwie” Janusz Radziwiłł. Ponieważ zaś dwór królewski nie miał zaufania do Szwedów, pogłębiało to rozbrat senatorów z Janem Kazimierzem ${ }^{9}$. Warto zauważyć, że rozumowaniu temu nie można zarzucić naiwności, najwyżej tylko brak dobrego rozeznania w planach szwedzkiego monarchy. Nowy król Szwecji (od 6 VI 1654) Karol X Gustaw skłaniał się bowiem początkowo, właśnie pod wpływem sukcesów moskiewskich w Polsce, do sojuszu przeciw Moskwie. Wysłał nawet do Polski agenta dyplomatycznego Jana Kocha, który stawił się w sierpniu 1654 r. w Warszawie $^{10}$. Jan Kazimierz, niepotrzebnie zwlekając, zdecydował się jesienią na wyprawienie własnego poselstwa do Sztokholmu. Chodziło mu jednak o wybadanie wstępnych warunków sojuszu i rekompensaty za zrzeczenie się tytułu króla szwedzkiego. Jak twierdzi Janusz S. Dąbrowski, senatorowie chcieli natomiast, aby posłowie polscy mieli pełne plenipotencje do szybkiego zawarcia sojuszu ze Szwecją ${ }^{11}$. Delegowany w poselstwie Andrzej Morsztyn, stolnik sandomierski, dotarł do Sztokholmu w styczniu 1655 r. Ponieważ jednak nie miał pełnomocnictw do zawarcia sojuszu ze Szwecją, nie został nawet przyjęty na audiencji przez Karola X Gustawa. Zdaniem Dąbrowskiego „zawód wywołany misją Morsztyna [--] na przełomie stycznia i lutego doprowadził króla szwedzkiego do podjęcia decyzji o ataku na Polskę"12. Pogląd ten nie jest odosobniony, gdyż również Robert Frost sądzi, że król szwedzki, rozważając atak na Moskwę, wiedział, iż jest on możliwy jedynie w sojuszu z Polską, gdyż w przeciwnym razie Rzeczpospolita może uderzyć razem z Rosją na Szwecję. Tak więc w sytuacji, gdy żądania Jana Kazimierza uniemożliwiały zawarcie przymierza, szwedzki monarcha miał niewielkie pole manewru i musiał uderzyć na państwo polsko-litewskie ${ }^{13}$.

$\mathrm{Na}$ konwokację senatu zwołaną przez Jana Kazimierza na marzec 1655 r. przybyło niewielu senatorów, co mogło świadczyć o ich zwątpieniu w króla lub o dużej opozycyjności większości członków wyższej izby parlamentu. Sejmiki zwołane przed sejmem na ogół poparły program królewski i uchwaliły pospolite ruszenie oraz wyprawę łanową. Tak więc społeczeństwo szlacheckie potraktowało sprawę zagrożenia kraju poważnie, choć liczono na sfinalizowanie pokoju z Karolem X Gustawem. Warto też

9 Ibidem.

10 J.S. Dąbrowski, Polskie elity wobec Szwecji w przededniu potopu, w: Z dziejów stosunków Rzeczypospolitej Obojga Narodów ze Szwecja, s. 92.

11 Ibidem, s. 93.

12 Ibidem, s. 94.

13 R.I. Frost, The Northern Wars 1558-1721, Harlow-London 2000, s. 167. 
podkreślić, że województwa poznańskie i kaliskie zmobilizowały, łącznie z pospolitym ruszeniem, aż 15 tys. wojska. Wadą tych oddziałów było przede wszystkim słabe wyszkolenie i niedostateczna ilość artylerii i piechoty.

Przypatrując się mobilizacjom poszczególnych województw koronnych i próbom podejmowania walki tak przez wojska regularne, jak i pospolitaków, widać, że co prawda przystąpiono do odparcia wroga, ale bez wiary w zwycięstwo. Przyznają to nawet ci historycy, którzy starają się umniejszyć załamanie morale społeczeństwa szlacheckiego w drugiej połowie 1655 r. Wiesław Majewski uważa, że „mimo okoliczności łagodzących należy w zasadzie surowo osądzać tych, którzy poddawali województwa, ziemie i powiaty, a więc części Rzeczypospolitej"14.

Warto zwrócić uwagę na dwa akty prawne, które towarzyszyły kapitulacjom wojsk polskich i litewskich. Chodzi oczywiście o układy ze Szwedami, zawarte pod Ujściem i w Kiejdanach. Senatorowie, którzy zadecydowali o owych porozumieniach z Karolem X Gustawem, a więc Krzysztof Opaliński, wojewoda poznański, i Janusz Radziwiłł, wojewoda wileński i hetman wielki litewski, byli od kilku lat skonfliktowani z Janem Kazimierzem, więcej - przynajmniej od $1653 \mathrm{r}$. istniało między nimi porozumienie dotyczące współdziałania politycznego. Akt kapitulacji zawarty 25 lipca przewidywał nie tylko poddanie się oddziałów wielkopolskich Wittenbergowi, ale także przyjęcie szwedzkiej protekcji nad województwami poznańskim i kaliskim. Monarsze szwedzkiemu przyznano ponadto wszystkie prerogatywy królewskie na tym obszarze. Można się zgodzić ze stanowiskiem Adama Kerstena, że oznaczało to w istocie oderwanie dwóch województw od Rzeczypospolitej ${ }^{15}$. Karol X Gustaw miał z kolei zagwarantować miejscowej szlachcie dotychczasowe prawa i pozycję polityczną, a także utrzymanie znaczenia wyznania katolickiego. Jeszcze w dniu kapitulacji, a więc 25 lipca, Hieronim Radziejowski, były podkanclerzy koronny, obecnie w służbie szwedzkiej, wystosował list do szlachty sieradzkiej, wzywając, aby postąpiła „exemplo inszych województw"16. I chociaż większość województw koronnych w ciągu października-listopada tak właśnie postąpiła, to paradoksalnie sieradzanie nie podpisali ani kapitulacji, ani tym bardziej aktu przyjęcia protekcji szwedzkiego monarchy ${ }^{17}$. Znane są daty przyjmowania tej opieki przez

${ }^{14}$ W. Majewski, Poddawanie się Szwedom w Koronie w 1655 roku, w: Z dziejów stosunków Rzeczypospolitej Obojga Narodów ze Szwecją, s. 116.

${ }_{15}$ A. Kersten, Hieronim Radziejowski. Studium władzy i opozycji, Warszawa 1988, s. 399.

16 Ibidem, s. 401.

${ }^{17}$ W Koronie nie podpisały tych aktów województwa: sieradzkie, płockie, chełmińskie, pomorskie i malborskie, a ponadto z obszarów zajętych przez Moskwę i Chmielnickiego: bracławskie oraz podolskie, W. Majewski, op. cit., s. 117. 
poszczególne województwa i ziemie. Następowało to z reguły po próbie stawiania oporu wojskom skandynawskim.

Przyjrzyjmy się bliżej aktowi zawartemu w Kiejdanach w dniu 20 października 1655 r. Analizujący ten traktat Andrzej Rachuba podkreśla beznadziejną sytuację militarną Litwy. Podjęta na początku 1655 r. kontrofensywa przeciw Moskwie, wspomagana przez posiłki koronne, załamała się na linii Mohylewa, a siły litewskie zostały rozbite. Po zajęciu Wilna przez Moskwę (8 sierpnia) i dotarciu na Litwę wieści o kapitulacji pod Ujściem, Janusz i Bogusław Radziwiłłowie oraz biskup wileński Jerzy Tyszkiewicz przedstawili ofertę przyjęcia warunkowej protekcji szwedzkiej nad Litwą, ale bez zrywania unii z Polską, przy czym Radziwiłłowie zażyczyli sobie księstwa dziedzicznego o ponad 100 tys. $\mathrm{km}^{2}$ powierzchni ${ }^{18}$. Oczywiście Szwedzi odrzucili tę propozycję. W wyniku rokowań toczonych od 17 sierpnia ostatecznie podpisano traktat dotyczący zawiązania unii między Wielkim Księstwem Litewskim a Królestwem Szwecji. W ten sposób formalnie przestała istnieć Rzeczpospolita Obojga Narodów. Akt podpisali: Janusz Radziwiłł, biskup żmudzki Piotr Parczewski oraz jako trzeci senator Wilhelm Holzschuher, kasztelan dorpacki, i 1100 litewskiej szlachty. Karol X Gustaw stawał się dziedzicznym władcą Litwy, tak więc powstały po zerwaniu unii lubelskiej nowy twór państwowy miał wyraźnie zmieniony ustrój, tym bardziej że wśród instytucji wymienionych w unii kiejdańskiej zabrakło sejmików i sejmu litewskiego ${ }^{19}$.

Z pewnością opuszczenie Polski przez Jana Kazimierza pogłębiło kryzys moralny społeczeństwa szlacheckiego, ale nie wydaje się, że ma rację Karol Żojdź, kiedy twierdzi, iż wyjazd króla przesądził o powodzeniu Karola X Gustawa ${ }^{20}$. Przeczą temu podstawowe fakty. Otóż polski monarcha przekraczał granicę 15 października. Wieść o tym musiała rozchodzić się błyskawicznie, a mimo to próby oporu przeciw Szwedom wciąż trwały. Jak stwierdza Majewski, dopiero porażka oddziału partyzanckiego na północnym Mazowszu spowodowała poddanie się dwa dni później ziemi różańskiej i zakroczymskiej, a w dniu 27 października także ziemi ciechanowskiej. Kolejne ziemie przyjęły szwedzką protekcję: łomżyńska 1 listopada, wiska 4 listopada. Ta sama porażka spowodowała także kapitulację województwa rawskiego 28 października i ziemi czerskiej 1 listopada. Przegrana szlachty łęczyckiej pod koniec października przyczyniła się do przyjęcia szwedzkiej protekcji przez ziemię wieluńską 4 listopada, a przez

18 A. Rachuba, J. Kiaupienè, Z. Kiaupa, Historia Litwy. Dwugłos polsko-litewski, Warszawa 2008, s. 102.

19 Ibidem, s. 103.

${ }^{20}$ K. Żojdź, Traktat z Radnot i udział Bogusława Radziwiłła w planach podziału Rzeczypospolitej, „Studia Historyczno-Wojskowe” 5, 2015, s. 178. 
województwo łęczyckie dopiero 30 listopada $^{21}$. Jak więc widać, opuszczenie kraju przez Jana Kazimierza nie spowodowało zaniechania oporu szlachty koronnej, choć niewątpliwie nie wzmacniało morale walczących.

Nie ulega jednak wątpliwości, że na jesieni 1655 r. król szwedzki mógł się poczuć triumfatorem, był bowiem nie tylko wielkim księciem litewskim, ale też szlachta z większości województw koronnych oddała się pod jego protekcję. Wydawać się zatem mogło, że państwo polsko-litewskie przestało istnieć, a król szwedzki zostanie wkrótce władcą, być może nawet dziedzicznym, koronnej części Rzeczypospolitej Obojga Narodów. Jak stwierdza Konopczyński, Karol X Gustaw został omamiony własnymi sukcesami i uwierzył w możliwość odebrania Janowi Kazimierzowi także Królestwa Polskiego. „W listopadzie miał się odbyć w Warszawie, zamiast formalnej elekcji, sejm hołdowniczy całej Polski. Nadspodziewanie nikt się nie zjawił. Zdobywca oprzytomniał i pomaszerował na północ wykańczać szwedzkie dominium maris baltici”22.

Absencję na sejmie hołdowniczym poprzedziły jednak dwa fakty. Po pierwsze, opór szlachty w poszczególnych województwach trwał aż do początków grudnia. Województwa brzesko-kujawskie i inowrocławskie podpisały deklarację przyjęcia szwedzkiej protekcji dopiero 30 listopada, szlachta oświęcimsko-zatorska 2 grudnia, dzień później zaś uczyniły to powiaty krakowski i czchowski²3. Po drugie, w województwach poznańskim i kaliskim zaczęła efektywnie działać partyzantka szlachecko-chłopska. Na początku października późniejszy legendarny przywódca partyzantów wielkopolskich, starosta babimojski Krzysztof Żegocki zdobył Kościan, a szwagier szwedzkiego monarchy landgraf heski Fryderyk stracił w tym starciu życie. Jak stwierdza Mirosław Nagielski, ten niewielki sukces „wzmógł działalność drobnych oddziałów złożonych ze szlachty, mieszczan i chłopów, które atakowały na Podgórzu Krakowskim znajdujące się tam nieliczne grupy Szwedów"24.

W dniu 18 listopada Szwedzi zaczęli oblężenie Jasnej Góry, a dwa dni później w Opolu Jan Kazimierz wydał uniwersał do wszystkich stanów Rzeczypospolitej, wzywający do powszechnego powstania przeciw nim. $\mathrm{Na}$ temat znaczenia oblężenia klasztoru paulinów dla wzmożenia oporu przeciw agresorowi toczone są spory. Nie wdając się w nie, chcielibyśmy podkreślić, że pierwsza poważna klęska armii szwedzkiej, która w sile

${ }^{21}$ W. Majewski, op. cit., s. 116-117.

22 W. Konopczyński, op. cit., s. 24.

${ }^{23}$ Wiesław Majewski uważa, że kapitulacja tych dwóch powiatów województwa krakowskiego była dziełem miejscowych arian (op. cit., s. 117).

${ }^{24}$ M. Nagielski, Koncepcje prowadzenia działań przeciwko Szwedom $w$ dobie potopu, w: Z dziejów stosunków Rzeczypospolitej Obojga Narodów ze Szwecja, s. 169. 
2 tys. żołnierzy nie zdołała przez kilka tygodni pokonać załogi niewielkiej fortecy, liczącej zaledwie 200 obrońców, musiała zrobić piorunujące wrażenie. Potęgował je fakt, że oblegającymi byli przeważający przecież w wojsku nieprzyjacielskim luteranie, a skutecznie bronili się katolicy.

Z kolei uniwersał królewski był reakcją monarchy na wzrastający w kraju opór przeciw najeźdźcy. Można postawić przewrotną hipotezę, że gdyby król nie opuścił kraju i wystosował pismo do narodu z terenu obejmującego około 10 proc. dawnej powierzchni państwa, który wówczas pozostał nieopanowany przez któregoś z nieprzyjaciół, wrażenie uniwersału byłoby mniejsze. Ponieważ jednak jego autor był człowiekiem, który zwątpił w moc państwa i narodu, bo przecież wyjechał za granicę, to siła jego argumentacji, gdy wzywał do stawiania oporu musiała być większa, gdyż wątpiący przestał wątpić.

Nie jest naszym celem analiza kolejnych faz walki ze Szwedami czy pozostałymi nieprzyjaciółmi, chcieliśmy natomiast podkreślić znaczenie końcówki roku 1655. Otóż Szwedzi zwinęli oblężenie Jasnej Góry w nocy z 26 na 27 grudnia, 29 tego miesiąca wojsko i szlachta zawiązali ogólnopolską konfederację przeciw Szwedom, natomiast Jan Kazimierz 18 grudnia wyruszył w drogę powrotną do Polski. Jeśli weźmiemy pod uwagę tę chronologię, to okaże się, że król wątpił w siły państwa i narodu około miesiąca, a wojsko koronne około dwóch miesięcy. Natomiast szlachcie wielkopolskiej analogiczny proces zajął również maksimum dwa miesiące. Załamanie morale społeczeństwa i jego elit trwało więc relatywnie krótko.

Powróćmy teraz do sytuacji na Litwie. Otóż nastąpiła szybka, negatywna reakcja na traktat kiejdański. Większość wojska litewskiego wypowiedziała posłuszeństwo hetmanowi wielkiemu i go opuściła. Chorągwie te w większości udały się pod Brześć Litewski, gdzie stały oddziały wojewody witebskiego Pawła Sapiehy i podkanclerzego litewskiego Kazimierza Lwa Sapiehy. Jak sądzi Krzysztof Kossarzecki, powołujący się na Rachubę, wojewoda witebski lawirował przez pewien czas między Karolem X Gustawem a carem Aleksym² ${ }^{25}$. Późną jesienią Paweł Sapieha wysłał poselstwo do cara z prośbą o pokój między Rzecząpospolitą a Moskwą. Uzyskał duży sukces, bo Aleksy zgodził się na zawieszenie broni na Litwie. Późną jesienią zgrupowanie Sapiehy pod Brześciem zdecydowało się przyjąć protekcję szwedzką ${ }^{26}$. Jak stwierdza Kossarzecki, okres schyłku

${ }^{25}$ K. Kossarzecki, Szlachta litewska wobec panowania szwedzkiego i moskiewskiego, w: Z dziejów stosunków Rzeczypospolitej Obojga Narodów ze Szwecja, s. 283; A. Rachuba, Pawet Sapieha wobec Szwecji i Jana Kazimierza (IX 1655 - II 1656), „Acta Baltico-Slavica” 11, 1977, s. $82-83,85-86$.

${ }^{26}$ Krzysztof Kossarzecki tłumaczy to naciskami wojsk moskiewskich (op. cit., S. 286). 
1655 i początek roku następnego na Litwie „charakteryzował się najgłębszym upadkiem nadziei na odrodzenie się Rzeczypospolitej"27. Szlachta oddawała się pod carską (częściej) lub szwedzką (rzadziej) protekcję. Z początkiem roku 1656 postawa Litwinów zaczęła się jednak zmieniać pod wpływem wieści przychodzących z Korony. Zaczęły bowiem dochodzić informacje o masowym porzucaniu przez szlachtę i wojsko Szwedów i o powrocie Jana Kazimierza do Rzeczypospolitej. Paweł Sapieha pod wpływem tych wieści zdecydował się w styczniu przejść na stronę króla, jednak do lutego nie podejmował formalnych kroków świadczących o zerwaniu z Karolem X Gustawem ${ }^{28}$. Wiosną 1656 r. wybuchło na Żmudzi powstanie antyszwedzkie. Charakterystyczna jest postawa powstańców, którzy, chcąc zabezpieczyć swoje rodziny przed ewentualnymi represjami ze strony Szwedów, przeprawiali się przez graniczną rzekę Świętą, za którą stały wojska carskie, tam składali przysięgę na wierność Moskwie, zostawiali rodziny i dobra ruchome, po czym wracali, aby kontynuować walkę z armią Karola X Gustawa ${ }^{29}$.

Pora na podsumowanie pierwszego etapu rozpadu Rzeczypospolitej Obojga Narodów. Symboliczny początek wyznaczają tutaj daty: 25 lipca (Ujście) i 20 października (Kiejdany). Z kolei dla procesu przezwyciężania kryzysu państwa polsko-litewskiego takie daty to: 18 grudnia - wyruszenie króla do kraju i 29 grudnia - konfederacja tyszowiecka. Ostatnią datą symboliczną jest 20 stycznia 1656 r., a więc dzień zawiązania przy Janie Kazimierzu ogólnopolskiej konfederacji w Łańcucie. Warto podkreślić, że udział czynników zewnętrznych w procesie wychodzenia z kryzysu był właściwie zerowy. Owszem, Jan Kazimierz jeszcze w sierpniu 1655 r. próbował uzyskać pomoc cesarską, ale bez rezultatu ${ }^{30}$. Podobnie spełzły na niczym starania podejmowane w tymże roku u cara Aleksego. Natomiast pomoc tatarska była przez cały czas, a więc nie miała zasadniczego wpływu na poderwanie całego społeczeństwa Rzeczypospolitej do walki ze szwedzkim najeźdźcą.

Rok 1656 rozpoczął okres stopniowego wypierania Szwedów z terenów państwa polsko-litewskiego. Proces ten był realizowany przede wszystkim przez siły własne wspomagane przez Tatarów, jednak czynnik

27 Ibidem, s. 290.

28 Ibidem, s. 290, 291.

29 Ibidem, s. 299.

30 Jedyne co wówczas uzyskano, to zapewnienie o mediacji cesarskiej w Moskwie. Faktycznie posłowie cesarza Ferdynanda III do cara Aleksego zaproponowali w drugiej połowie 1655 r. mediację między Rzecząpospolitą a Rosją, Z. Wójcik, Polska i Rosja wobec wspólnego niebezpieczeństwa szwedzkiego w okresie wojny pótnocnej 1655-1660, w: Polska w okresie drugiej wojny pótnocnej, t. 1, s. 344-345. 
zewnętrzny zaczynał odgrywać już pewną rolę. Przede wszystkim swoją postawę wobec Rzeczpospolitej zmieniła Moskwa. Chociaż nie doszło na razie do formalnego zawieszenia broni, to faktycznie wojska moskiewskie już od schyłku 1655 r. nie atakowały ani konfederatów podlaskich, ani armii Pawła Sapiehy. Nie chcąc dopuścić do nadmiernego wzmocnienia Szwecji, oddziały moskiewskie już w kwietniu 1656 r. uderzyły na zajęte przez Szwecję Inflanty.

Równolegle do tego procesu uaktywniły się dyplomacje cesarska i polska. Na początku 1656 r. car odpisał cesarzowi, że zgadza się na mediację Ferdynanda III, a Jan Kazimierz uczynił to samo w marcu tegoż roku ${ }^{31}$. Wcześniej, bo już w lutym wyruszyło polskie poselstwo do Moskwy, które dotarło do celu w kwietniu. Wkrótce zawarto formalne zawieszenie broni, na mocy którego Moskwa miała nie zajmować terenów wolnych lub okupowanych przez Szwedów. Ponadto car zgodził się wypuścić $\mathrm{z}$ niewoli wielu polskich jeńców wojennych. Z kolei od sierpnia toczyły się w Niemieży pod Wilnem rokowania polsko-moskiewskie za pośrednictwem poselstwa habsburskiego. Traktat o przymierzu zawarto ostatecznie 3 października. Zgodzono się na elekcję vivente rege cara Aleksego, ale miał on być koronowany dopiero po śmierci Jana Kazimierza. Wojska polskie i moskiewskie miały współdziałać w wojnie ze Szwecją i Brandenburgią. Równocześnie strony zobowiązywały się nie zawierać separatystycznego pokoju ze Szwecją. Jak słusznie stwierdza Wójcik, traktat w Niemieży był „bezsprzecznie wielkim wydarzeniem w dziejach wojny północnej" 32 . Przez dłuższy czas prowadzono też równolegle rokowania z cesarzem Ferdynandem III. Porozumienie zawarto dopiero 1 grudnia w Wiedniu. Rzeczpospolita otrzymywała pomoc 4 tys. żołnierzy cesarskich, ale zaciągniętych na polski koszt. Poza tym Habsburg oferował pomoc dyplomatyczną na dworze duńskim. Historycy zgodnie podkreślają, że nie była to pomoc dostateczna ${ }^{33}$.

Podsumujmy sytuację u schyłku roku 1656. Rzeczpospolita Obojga Narodów istnieje ponownie jako państwo polsko-litewskie, choć większość terytoriów jest pod okupacją moskiewską, szwedzką lub kozacką. Przezwyciężony został kryzys moralny, a wszystkie stany biorą udział w wojnie ze szwedzkim najeźdźcą. Stopniowo kurczy się obszar zajęty przez Skandynawów. Polska zyskuje nowego sojusznika w postaci państwa moskiewskiego. Tym samym, przynajmniej teoretycznie, ograniczone

31 Ibidem, s. 346.

${ }^{32}$ Ibidem, s. 368.

${ }^{33}$ W Konopczyński, op. cit., s. 30; R.I. Frost, After the Deluge. Poland-Lithuania and the Second Northern War 1655-1660, Cambridge 1993, s. 84. 
zostają możliwości wrogiego działania Bohdana Chmielnickiego. Rzeczpospolita uzyskuje także niewielką na razie pomoc militarną od Ferdynanda III. Nie musi więc walczyć ze Szwedami i Brandenburczykami, wspierana jedynie przez sojuszników tatarskich. A co ważne, odzyskuje, przynajmniej częściowo, podmiotowość na arenie międzynarodowej.

Już na przełomie 1655 i 1656 r. Karol X Gustaw zdał sobie sprawę, że podbój całej Rzeczypospolitej będzie niemożliwy. Próba uczynienia z Brandenburgii sojusznika drugiej rangi, jaką podjął szwedzki monarcha 17 stycznia 1656 r. w traktacie królewieckim (warunki: 1500 posiłków brandenburskich i pozycja lennika szwedzkiego z księstwa pruskiego, Warmia dla elektora), zawiodła m.in. z powodu załamania się skandynawskiej ofensywy wiosną i latem tego roku. Karol X Gustaw postanowił zatem nakłonić elektora do bardziej wydajnej pomocy. W traktacie malborskim z 25 czerwca Fryderyk Wilhelm otrzymywał oprócz obiecanej już Warmii, województwa: poznańskie, kaliskie, sieradzkie z ziemią wieluńską i województwo łęczyckie. Pozostawał jednak w dalszym ciągu lennikiem szwedzkim z Prus Książęcych. W zamian miał się włączyć do wojny z Polską całością swych sił. Jeśli porozumienie to zinterpretujemy jako podzielenie się z Hohenzollernami częścią Rzeczypospolitej, to można w tym widzieć pierwszą przymiarkę do rozbioru. Kolejny układ z domem brandenburskim łączył się już wyraźnie z planami rozbiorowymi Rzeczypospolitej. Zawarto go bowiem 20 listopada, a więc w momencie, gdy toczyły się pełną parą rokowania rozbiorowe z Siedmiogrodem. Elektor terytorialnie niczego więcej nie otrzymał, uzyskiwał natomiast suwerenność w księstwie pruskim, a więc stawał się formalnie równorzędnym partnerem Szwecji. Traktat w Labiawie (Labiau) z listopada był w gruncie rzeczy pierwszym etapem realizacji rozbioru Rzeczypospolitej, bowiem Karol X Gustaw zastrzegał w nim dla siebie Prusy Królewskie, Kujawy, północną część Mazowsza, Żmudź i zachodnią część Litwy.

Pora na przybliżenie stanowiska pozostałych kontrahentów rozbiorowych. Bohdan Chmielnicki, zmieniający dość często opcje polityczne, jak już wspomniano, zwracał się do księcia Jerzego II Rakoczego w 1648 r. W 1653 stosunki obustronne stały się wrogie, a Siedmiogród został na blisko dwa lata sojusznikiem Polski w walce z Kozakami. Jednak już w sierpniu 1655 r., pod wpływem klęsk Rzeczypospolitej, władca siedmiogrodzki nawiązał bliższe kontakty z hetmanem kozackim. Zostały one pogłębione latem roku następnego. Jak stwierdza Żojdź, Chmielnickiego do opcji siedmiogrodzkiej popchnęło niedopuszczenie jego przedstawicieli do rokowań w Niemieży ${ }^{34}$. Oczywiście hetman kozacki nie byłby

${ }^{34}$ K. Żojdź, op. cit., s. 182. 
sobą, gdyby z tej okazji zerwał całkowicie z carem Aleksym. W dniu 7 września w Alba Julia poselstwo kozackie zawarło traktat o wieczystej przyjaźni z Siedmiogrodem. Obie strony zobowiązały się do udzielenia sobie pomocy wojskowej w ciągu dwóch tygodni od rozpoczęcia działań przeciw Polsce.

Jerzy II Rakoczy już w marcu 1655 r. zaproponował Szwedom ściślejszą współpracę. Wprawdzie propozycja nie została przyjęta, ale szwedzki monarcha zapewnił władcę Siedmiogrodu o swej przyjaźni. Rok później Rakoczy ponowił swoją ofertę. Tym razem okoliczności były inne, a pozycja szwedzka w Rzeczypospolitej niepewna. Karol X Gustaw zdecydował się zatem dopuścić Jerzego II Rakoczego do podziału państwa polsko-litewskiego. Żojdź uważa, że z inicjatywą rozbioru wyszedł książę siedmiogrodzki, choć przyznaje, że bez przychylności szwedzkiego monarchy nic by z tych zamierzeń nie wyszło ${ }^{35}$. Wydaje się jednak, że rację ma raczej Konopczyński, porównując władcę skandynawskiego jako inicjatora rozbioru do króla pruskiego Fryderyka Wielkiego ${ }^{36}$. Poselstwo szwedzkie dotarło do Siedmiogrodu dopiero w sierpniu 1656 r., a rokowania trwały aż do 6 grudnia. Zarówno Frost, jak i Żojdź stwierdzają, że traktat w Radnot podpisali jedynie reprezentanci Szwecji i Siedmiogrodu ${ }^{37}$. Fakt ten nie pomniejsza jednak znaczenia porozumienia, gdyż z treści wynika wyraźnie, że uwzględnieni w nim zostali pozostali kontrahenci. Jeśli weźmiemy pod uwagę, że Fryderyk Wilhelm otrzymał dokładnie to, co uzyskał w Labiawie, to obecność jego przedstawicieli w Radnot nie była w ogóle konieczna. Podobnie przedstawia się sprawa z Bohdanem Chmielnickim. Hetman zaporoski już w sierpniu 1655 r. nawiązał kontakt ze Szwedami. Następnie, wobec posła Karola X Gustawa, uznał szwedzką protekcję ${ }^{38}$. W drugiej połowie roku następnego, po osłabieniu pozycji szwedzkiej w Polsce, Kozacy wznowili rokowania i ze Szwedami, i z Rakoczym. W ich rezultacie zostali uwzględnieni w podziale Rzeczypospolitej Obojga Narodów, ale ich obecność w Radnot, podobnie jak Brandenburczyków, nie była konieczna, gdyż warunki ustalono wcześniej. Wreszcie ostatni kontrahent rozbiorowy to koniuszy litewski Bogusław Radziwiłł. Tadeusz Wasilewski był przekonany, i chyba słusznie, o jego udziale w tworzeniu nowej koalicji przeciw Rzeczypospolitej w drugiej połowie $1656 \mathrm{r} .{ }^{39}$ Po krótkiej niewoli w wojsku hetmana

35 Ibidem, s. 191.

${ }^{36}$ W. Konopczyński, op. cit., s. 32.

37 R.I. Frost, After the Deluge, s. 85; K. Żojdź, op. cit., s. 185.

${ }^{38}$ M. Stangreciuk, op. cit., s. 218.

${ }^{39}$ Bogusław Radziwiłł, Autobiografia, wstęp i oprac. T. Wasilewski, Warszawa 1979, s. 65 . 
polnego litewskiego Wincentego Gosiewskiego (8-22 października) nie powrócił on do służby szwedzkiej, łącząc własne losy ze swym kuzynem, elektorem brandenburskim. Nie ulega wątpliwości, że podobnie jak Bohdan Chmielnicki, tak i Bogusław Radziwiłł był uczestnikiem paktu rozbiorowego drugiego gatunku. Obecność jego przedstawiciela na rokowaniach nie była w związku z tym konieczna.

Przedstawiliśmy na początku naszych rozważań zarys podziału zdobyczy terytorialnych pomiędzy zaborcami. Dwie kwestie wymagają jednak uzupełnienia. Otóż Kurlandia, która znalazła się w szwedzkiej strefie rozbiorowej, nie miała być inkorporowana do północnego królestwa, ale stać się lennem Karola X Gustawa. Druga kwestia dotyczy powiatu wołkowyskiego, leżącego w szwedzkim „zaborze”, który wymieniają niemal wszyscy historycy piszący o układzie z Radnot. Istotnie w tekście traktatu występuje taka nazwa. Jednak, jak słusznie zwrócił uwagę Żojdź, nie może chodzić o powiat wołkowyski, gdyż ten należał do województwa nowogrodzkiego, które miało być w całości lennym księstwem dziedzicznym koniuszego litewskiego. Uważa zatem, że musiało chodzić o powiat wiłkomierski województwa wileńskiego, który nie był zajęty przez wojska moskiewskie ${ }^{40}$. Dodać tu można, że w języku łacińskim obydwie nazwy brzmiały bardzo podobnie.

Poddając analizie pierwszą próbę rozbioru Rzeczypospolitej Obojga Narodów, warto zwrócić uwagę, że granice niektórych stref były dość płynne. Ściślejsze rozgraniczenie miało dopiero nastąpić. Właściwie precyzyjnie były wyodrębnione tylko trzy zabory: szwedzki, brandenburski i księcia Bogusława Radziwiłła. O tym, jak wielkie mają być pozostałe części, miano zadecydować później i nie chodziło tylko o granice między Siedmiogrodem i posiadłościami kozackimi czy Rakoczym a Szwedami. Ważniejsza była bowiem kwestia, pominięta zresztą w traktacie milczeniem, terytoriów zajętych przez Moskwę. To wszystko stanowiło element konfliktogenny. Drugim czynnikiem, który mógłby w przyszłości poróżnić zaborców, była Litwa. Traktat nie rozstrzygał jednoznacznie, kto ma prawo do tytułu wielkiego księcia litewskiego. Na mocy ugody kiejdańskiej, dziedzicznym, wielkim księciem litewskim został Karol X Gustaw, a przecież Jerzy II Rakoczy miał zostać królem Polski i nie jest wykluczone, że marzył również o tronie litewskim. Najprawdopodobniej musiałoby dojść do konfliktu samozwańczego króla polskiego z samozwańczym wielkim księciem litewskim. Jeśli dodamy do tego niechęć Moskwy wobec wzrostu znaczenia Bohdana Chmielnickiego, to widać wyraźnie, że przed zaborcami nie rysowała się optymistyczna przyszłość.

${ }^{40}$ K. Żojdź, op. cit., s. 186. 
W styczniu 1657 r. na teren województwa ruskiego, jak napisał Konopczyński: „bez rozumnego planu, pod złymi auspicjami, zewsząd ostrzegany przed nierozważnym krokiem", wkroczył książę Jerzy II Rakoczy ${ }^{41}$. Przebieg jego wyprawy i kampanii szwedzkiej w 1657 r. są dobrze znane. Przypomnijmy tylko, że epizod niedoszłego polskiego monarchy zakończył się ostatecznie kapitulacją wojsk Siedmiogrodu pod Czarnym Ostrowem (27 VII 1657). W odwrocie Węgrzy zostali rozbici przez Tatarów pod Międzyborzem w dniach 1-2 sierpnia.

Wszyscy niedoszli zaborcy nie wzięli pod uwagę wielu istotnych czynników. O niektórych mówiliśmy już powyżej. Siedmiogród nie przewidział reakcji cesarza. Otóż następca Ferdynanda III, Leopold I, zgodził się w traktacie wiedeńskim z 27 maja 1657 r. przysłać Janowi Kazimierzowi posiłki w liczbie 12 tys. żołnierzy, którzy mieli być zresztą na żołdzie Rzeczypospolitej. Na sukcesy szwedzkie zareagowała ponadto Dania. W czerwcu 1657 r. wypowiedziała wojnę Szwecji. Pierwszy etap działań zakończył się klęską wojsk króla Fryderyka III i utratą posiadłości leżących na południu półwyspu skandynawskiego. W drugiej fazie walk, toczonych w 1658 r., Duńczycy otrzymali jednak pomoc cesarską i polską. Paradoksalnie zatem pierwsza próba rozbiorowa nie tylko nie zlikwidowała państwa polsko-litewskiego, ale doprowadziła do powstania koalicji antyszwedzkiej, w skład której weszli: cesarz Leopold I, Dania, Moskwa, Rzeczpospolita, Tatarzy, a następnie nawet Brandenburgia. Warto jednak zwrócić uwagę na fakt, że zanim powstała tak wielka koalicja, państwo polsko-litewskie w 1657 r. poradziło sobie z atakiem Siedmiogrodzian, wspomaganych przez posiłki mołdawsko-wołoskie, Szwedów, Brandenburczyków i Kozaków zaporoskich. Ma niewątpliwie rację Stangreciuk, twierdzący, że traktat z Radnot nie miał szansy „na pełną realizację"42. Dodać można jeszcze jeden czynnik, który przyczynił się do fiaska zaborczych planów. Chodzi mianowicie o dużą liczbę uczestników planów rozbiorowych. Formalnie było ich pięciu. Jeśli jednak weźmiemy pod uwagę, że Jerzy Rakoczy zaproponował hospodarom Mołdawii i Wołoszczyzny Kamieniec Podolski i Jazłowiec w zamian za posiłki, które oni zresztą w postaci 6 tys. żołnierzy przysłali, to liczba zaborców wzrasta do siedmiu. I już to samo musiało w przyszłości prowadzić do konfliktów ${ }^{43}$.

Pierwsza próba rozbioru zmobilizowała dodatkowo tak monarchę i elity polityczne, jak i społeczeństwo szlacheckie nie tylko do nadzwyczajnych wysiłków militarnych, ale także do przeprowadzenia różnych

\footnotetext{
${ }^{41}$ W. Konopczyński, op. cit., s. 32.

${ }^{42}$ K. Żojdź, op. cit., s. 223.

43 M. Stangreciuk, op. cit., s. 218.
} 
posunięć natury ustrojowej, które miały charakter tak niecierpianych przez szlachtę novitates. Pomimo generalnej niechęci polskich panujących do powoływania konfederacji szlacheckich przy swoim boku, Jan Kazimierz w styczniu 1656 r. przystąpił w Łańcucie do konfederacji tyszowieckiej. Na jej mocy możliwe było funkcjonowanie w latach 1656-1658 konwokacji senatu. Decydowały one o podatkach, polityce zagranicznej, zawieraniu sojuszy militarnych i przystępowaniu do wojny. W marcu 1657 w Częstochowie i w lutym 1658 r. w Warszawie obradowały one z udziałem przedstawicieli szlachty wybranej przez sejmiki ${ }^{44}$. Dodać należy, że na obradach nie obowiązywało liberum veto i procedowano według zasad głosowania większościowego. Kres temu interesującemu eksperymentowi ustrojowemu położyło zwołanie sejmu w 1658 r. do Warszawy. Jednak i na tym sejmie dokonano rzeczy niezwykłej. Przeprowadzono mianowicie elekcję vivente rege cara moskiewskiego. Nie został królem Polski przede wszystkim dlatego, że nie chciał spełnić warunku sine qua non i nie przeszedł na katolicyzm. Kolejnym bezprecedensowym wydarzeniem było zawarcie unii z Kozaczyzną w Hadziaczu. Wprowadzała ona na miejsce podwójnej Rzeczypospolitej państwo potrójne, złożone z Polski, Litwy i Rusi, zwanej oficjalnie Księstwem Ruskim. Choć żywot Rzeczypospolitej Trojga Narodów był krótki, to jej kres był wynikiem separatyzmu większości Kozaków, a nie niechęci społeczeństwa szlacheckiego. Nie ulega zatem wątpliwości, że państwo polsko-litewskie w trakcie wychodzenia z kryzysu wykazało dużą żywotność, a załamanie trwało krótko, zaledwie kilka miesięcy. Paradoksalnie próba rozbioru przyszła w momencie, gdy kryzys był już dawno opanowany i Rzeczpospolita przechodziła do kontrofensywy wobec najgroźniejszego wroga - Szwecji.

2 .

Powstają jeszcze do rozważania trzy kwestie. Czy traktat w Radnot można nazwać próbą rozbiorową? Czy można go porównywać z rozbiorami Polski z drugiej połowy XVIII stulecia oraz czy można zauważyć w XVII w. inne próby odbudowy państw, które przestały istnieć bądź utworzenia państw, które wcześniej nie istniały? Wreszcie czy w tym czasie mamy

${ }^{44}$ E. Opaliński, Społeczeństwo szlacheckie wobec Rzeczypospolitej Obojga Narodów w okresie 1572-1668. Reakcja na spadek efektywności państwa, w: My i oni. Społeczeństwo nowożytnej Rzeczypospolitej wobec państwa, red. W. Kriegseisen, Warszawa 2016, s. 40, 42; R.I. Frost, After the Deluge, s. 91-92, 117-119. 
do czynienia również z innymi usiłowaniami likwidacji bądź podporządkowania sobie państw?

Polska historiografia na ogół dość zgodnie traktuje traktat z Radnot jako pierwszą próbę rozbioru państwa polsko-litewskiego. Ostatnio jednak pokuszono się o zakwestionowanie tego przekonania, a uczynił to Karol Żojdź. Na rzecz swego twierdzenia przytacza argument, że Austria, Prusy i Rosja były równoprawnymi partnerami, a w wypadku traktatu zawartego w Siedmiogrodzie mamy do czynienia z jednym hegemonem, czyli Szwecją, oraz pozostałymi, mniejszymi partnerami. Oczywiście badacz ma rację, mówiąc o przewadze Szwecji wobec pozostałych kontrahentów, wśród których było zresztą pewne zróżnicowanie. Jednak między zaborcami osiemnastowiecznymi także istniały różnice. Rosja była niewątpliwie państwem silniejszym od Prus i Austrii. Kolejny argument Żojdzia to stwierdzenie, że Austria, Prusy i Rosja uszanowały podziały wewnętrzne w państwie polsko-litewskim, a kontrahenci z Radnot tego nie uczynili ${ }^{45}$. Argumentacja ta nie wytrzymuje jednak krytyki. Otóż zarówno w 1656 r., jak i w okresie 1772-1795 nie respektowano w pełni granic wewnętrznych w Rzeczypospolitej. Przyjrzyjmy się pierwszemu zaborowi pruskiemu. Jak można nie zauważyć, że Prusy zajęły wówczas tylko część województwa poznańskiego i kaliskiego, większą część województwa pomorskiego, bo przecież Gdańsk pozostał przy Rzeczypospolitej, większą część województwa inowrocławskiego i mniejszą część województwa brzesko-kujawskiego? To samo dotyczy zaboru austriackiego i rosyjskiego. Jeśli chodzi zaś o pozostałe argumenty Żojdzia, to co prawda są one słuszne, ale nie mają żadnego znaczenia. Owszem, wskazują na różnicę odnośnie do stosunku sąsiadów do kwestii rozbiorów i podnoszą problem siły Jana Kazimierza popieranego przez społeczeństwo. Czy jednak z faktu, że inna była postawa części sąsiadów Rzeczypospolitej i większa siła militarna polskiego monarchy w 1656 i 1657 r. niż w latach 1772-1795 można wyciągać wniosek, że w 1656/1657 część naszych sąsiadów nie próbowała dokonać rozbioru państwa polsko-litewskiego? Naszym zdaniem takiego wniosku wyciągać nie można.

Czy pierwszą próbę rozbiorową można porównać z rozbiorami Rzeczypospolitej w XVIII w.? Jest to działanie dość ryzykowne, choćby $\mathrm{z}$ tego względu, że traktat $\mathrm{z}$ Radnot był projektem nieudanym, a rozbiory wprost przeciwnie. Co więcej, ta pierwsza siedemnastowieczna próba była dość chaotyczna, tworzona poniekąd ad hoc, w odpowiedzi na niekorzystny rozwój sytuacji na polu militarnym. Szwecja szukała sojuszników. W sumie chętnych do podzielenia się ogromnym terytorium

${ }^{45}$ K. Żojdź, op. cit., s. 187. 
Rzeczypospolitej było siedmiu, w tym właśni obywatele. W drugiej połowie XVIII w. decyzję o unicestwieniu państwa polsko-litewskiego podjęły sąsiadujące z nim mocarstwa: Rosja, Austria i Prusy (wśród sąsiadów zabrakło jedynie Mołdawii, ale też ona nie była mocarstwem). Kolejna różnica wynika z tego, że w 1656 r. podjęto tylko jedną próbę rozbiorową, natomiast w XVIII w. proces rozbioru Rzeczypospolitej był rozłożony w czasie. Jak się wydaje, powolna śmierć państwa polskiego była i dla jej obywateli, i dla Europy mniejszym szokiem, niż jej natychmiastowe unicestwienie. Zaborcy działali zresztą w sposób przemyślany i dobrze zorganizowany.

Warto jednak przedstawić jeszcze dwie poważne różnice między traktatem z Radnot i rozbiorami osiemnastowiecznymi. Po pierwsze, inny był układ sił międzynarodowych w obu tych okresach i różna reakcja na próbę parcelacji Polski. Po drugie, inny był potencjał państwa. Na bezprecedensowe sukcesy Szwedów w 1655 r. zareagowali zaniepokojeni najważniejsi sąsiedzi Rzeczypospolitej. Cesarz Ferdynand III zgodził się udzielić wsparcia czterotysięcznymi posiłkami, a jego syn Leopold I zawarł sojusz z państwem polsko-litewskim i pomoc militarną zwiększył do 12 tys. żołnierzy. Podobnie ewoluowała postawa Moskwy. Rosjanie, będąc najpierw w stanie wojny z Rzecząpospolitą, zawarli z nią zawieszenie broni, następnie rozejm i formalne przymierze antyszwedzkie. Do zawiązującej się koalicji antyszwedzkiej przystąpiła także Dania, a w 1657 r. również niedoszły zaborca mianowicie Brandenburgia. Co więcej, Polska była od 1654 r. w sojuszu z chanem krymskim Islamem Girejem. Nigdy więc podczas „potopu” nie była całkiem osamotniona.

W czasie panowania Stanisława Augusta Poniatowskiego położenie międzynarodowe było odmienne. Po pierwsze, Rzeczpospolita przestała już dawno być mocarstwem, a w połowie XVII w. była nim niewątpliwie. Więcej, w trakcie „potopu” najbardziej znaczącym państwem rozbiorowym była Szwecja. Pozostali to w tym czasie mali gracze. Karierę mocarstwową, głównie kosztem Polski w XVIII w., zrobiła jedynie Brandenburgia. Tak więc otoczenie międzynarodowe było w obu porównywanych okresach diametralnie różne. Korzystniejsze dla państwa polsko-litewskiego w XVII stuleciu i fatalne sto lat później.

Drugi aspekt dotyczy siły wewnętrznej Rzeczypospolitej. Podczas „potopu” państwo polsko-litewskie samodzielnie, jedynie w sojuszu z Tatarami, wyszło obronną ręką z największego kryzysu, jaki stanowił czas między lipcem 1655 a schyłkiem tego roku. Na pierwszy rozbiór (1772) ani państwo, ani społeczeństwo szlacheckie nie było w stanie zareagować oporem czy nawet sprzeciwem (nie licząc posłów Samuela Korsaka i Tadeusza Reytana). Zadecydowała o tym wielka nierównowaga 
militarna na korzyść zaborców, a przede wszystkim świeża klęska konfederacji barskiej. Można też zwrócić uwagę, że sama konfederacja cieszyła się pewną sympatią, a nawet poparciem Francji i Turcji. Po drugim rozbiorze nie było przez pewien czas widocznej społecznej reakcji. I choć Rzeczpospolita przegrała wojnę z Rosją w 1792 r., to wola walki o własne państwo nie zagasła i kilkanaście miesięcy później wybuchło powstanie Tadeusza Kościuszki. Próba ta nie dała pozytywnego rezultatu z powodu rażącej dysproporcji sił. Tak więc sytuacja w czasach „potopu” była pod tym względem dużo korzystniejsza.

Czy w ciągu XVII stulecia można zaobserwować udane bądź nieudane próby odbudowy państw, które istniały uprzednio, a zostały zjednoczone bądź włączone w inne organizmy państwowe? Jak się wydaje, można dostrzec dwa takie procesy na Półwyspie Iberyjskim i trzeci na terenie Rzeczpospolitej Obojga Narodów. Mamy oczywiście na uwadze próby utworzenia państwa kozackiego, czynione usilnie przez Bohdana Chmielnickiego. Jeśli chodzi o królestwo Hiszpanii, to udany przypadek dotyczy Portugalii, a nieudany północnej części Aragonii czyli Katalonii.

Przyjrzyjmy się pokrótce czynnikom odgrywającym istotną rolę w tych procesach. Portugalia w 1580 r. połączyła się z Hiszpanią unią personalną. Ostatni król Portugalii z dynastii Avis, Henryk, zmarł bezpotomnie właśnie w tymże roku, nie uregulowawszy kwestii następstwa tronu. Pretendentów do panowania w Lizbonie było kilku. Poparciem większości warstw plebejskich cieszył się Antonio, nieślubny syn infanta Luisa Avis. Drugim kandydatem był książę Bragança i jego żona księżna Katarzyna Avis, córka księcia Avis Duarte i wnuczka króla Emanuela I. Książę, którego popierała część szlachty i magnaterii, zachowywał jednak dużą ostrożność z obawy przed najsilniejszym rywalem, królem Hiszpanii Filipem II. Ten ostatni miał bowiem za sobą większość szlachty i magnaterii. Był on żonaty z księżniczką Marią, córką króla Jana III z dynastii Avis. Co prawda Antonio został proklamowany królem Portugalii, ale nie przeszkodziło to w koronacji Filipa II na władcę portugalskiego w grudniu 1580 r. Opór zwolenników Antoniego trwał pięć lat i był świadectwem tego, że część Portugalczyków traktowała rządy Hiszpanów jako obce ${ }^{46}$. Dopóki jednak Hiszpania odnosiła sukcesy na arenie międzynarodowej, unia z tym królestwem nie była w Portugalii kwestionowana. Zmianę sytuacji spowodowało włączenie się króla Filipa IV do wojny trzydziestoletniej. Klęski hiszpańskie oznaczały bowiem wymierne straty Portugalii. Największe wrażenie zrobiła utrata Brazylii, zdobytej przez Holandię.

${ }^{46}$ A.H. de Oliveira Marques, Historia Portugalii, t. 1: Do XIII wieku, Warszawa 1987 (oryg. portug. 1972), s. 290-292. 
Gdy w 1640 r. wybuchło powstanie antyhiszpańskie w Katalonii, stało się ono katalizatorem powstania w Portugalii. Szlacheckich spiskowców poparł praktycznie cały naród. Królem proklamowany został książę Jan Bragança, potomek księcia Bragança i księżnej Katarzyny Avis. Cała Portugalia i wszystkie posiadłości zamorskie, z wyjątkiem Ceuty, uznały jego władzę. Sytuacja międzynarodowa nowego państwa nie należała do łatwych. Wprawdzie cieszyło się ono pewnym poparciem Francji, ale już Holandia usiłowała pozbawić je posiadłości zamorskich. Tak więc Portugalia musiała toczyć walki na kilku frontach jednocześnie. Na szczęście dla niej Hiszpania miała wiele kłopotów na arenie międzynarodowej, a poza tym musiała borykać się z powstaniem w Katalonii. Wygrana przez Portugalczyków bitwa pod Montes Clares w 1665 r. przesądziła o zawarciu pokoju i ostatecznym uznaniu niepodległości ich państwa przez Hiszpanię w roku 1668.

Inny charakter miało powstanie w Katalonii, a więc północnej części dawnego królestwa Aragonii. Wybuchło ono, jak już wspomniano, w 1640 r. Powstańcy opanowali większość terytorium, łącznie ze stolicą w Barcelonie. $O$ ile jednak zdecydowano się na zrzucenie panowania hiszpańskiego, o tyle stany katalońskie nie dążyły do odzyskania niepodległości przez hrabstwo Barcelony, ale oddały się pod protekcję francuską; królowi Ludwikowi XIII przyznały w 1641 r. tytuł hrabiego Barcelony. Zamieniono zatem panowanie hiszpańskie na francuskie. To ostatnie w połączeniu z prowadzeniem wojny z Hiszpanią na terenie Katalonii doprowadziło wkrótce do wzrostu nastrojów antyfrancuskich. W 1652 r. wojska hiszpańskie zdobyły Barcelonę i opanowały teren zbuntowanej prowincji. W rezultacie Katalonia pozostała w Hiszpanii i utraciła na rzecz Francji północną część terytorium - hrabstwo Roussillion ${ }^{47}$. Przypadek Katalonii był zatem diametralnie różny od portugalskiego. Przede wszystkim samo społeczeństwo stanowe nie chciało niepodległości. Część wręcz chciała utrzymać związki z Kastylią, a większość przez pewien czas preferowała francuską protekcję. W tej sytuacji nowe państwo nie mogło powstać.

Wreszcie ostatni przypadek - próba utworzenia państwa kozackiego na czele z Bohdanem Chmielnickim. Wspominaliśmy już powyżej, że Kozaczyzna pod rządami Chmielnickiego zaczęła stosunkowo szybko przejawiać tendencje separatystyczne. Chęć oderwania się od państwa polsko-litewskiego lub uzyskania $\mathrm{w}$ jego ramach nadzwyczajnej pozycji pojawiła się po pierwszych poważnych sukcesach militarnych, a więc już w maju 1648 r., kiedy przywódca kozacki wysłał poselstwo do Rakoczego

47 T. Miłkowski, P. Machcewicz, Historia Hiszpanii, Wrocław 1998, s. 176. 
z propozycją, aby ubiegał się on o tron polski. W tym samym roku hetman wyprawił także poselstwo do cara Aleksego z prośbą o przyjęcie Kozaków pod swoją protekcję. Ugodę zborowską można oczywiście potraktować jako powrót do związków z Rzecząpospolitą, ale na warunkach kozackich. W roku następnym $\mathrm{w}$ rachubach Chmielnickiego zwyciężyła opcja turecka, która w jego wyobrażeniach miała umożliwić oderwanie się od Polski i pozwolić na dalszą budowę kozackiego państwa, którego podwaliny stawiał zresztą hetman po pierwszych sukcesach militarnych w 1648 r. Zwycięstwo wojsk Jana Kazimierza pod Beresteczkiem przesądziło o ponowieniu związków z Rzecząpospolitą, ale na gorszych warunkach dla Kozaków niż w ugodzie zborowskiej. W latach 1652-1653 mamy do czynienia z przedostatnią próbą uzyskania prawdziwej niepodległości przez państwo kozackie. Po pierwszych sukcesach (klęska Polaków pod Batohem i ślub Tymofieja $\mathrm{z}$ hospodarówną mołdawską Rozandą) przyszło jednak załamanie planów niepodległościowych na skutek ofensywy koalicji Rzeczypospolitej, Siedmiogrodu i Wołoszczyzny. Wówczas to hetman zaporoski zdecydował się na najgorszą z możliwych opcji - mianowicie moskiewską (traktat perejasławski 1654). Wreszcie w okresie 1656-1657 nastąpiła ostatnia próba wybicia się na niepodległość poprzez udział w układach w Radnot i uczestniczenie w kampanii Rakoczego w Polsce w roku 1657. Załamanie się koncepcji dokonania pierwszego rozbioru Rzeczypospolitej Obojga Narodów oznaczało także ostateczny upadek dążeń niepodległościowych Hetmanatu. Kozakom pozostało opowiedzenie się za jedną z trzech możliwości: związkiem z państwem polsko-litewskim, związkiem z Moskwą lub uznaniem protekcji tureckiej. Ostatecznie zwyciężyła opcja moskiewska, co z czasem doprowadziło do unicestwienia organizacji kozaków zaporoskich przez carycę Katarzynę II.

Czy Kozaczyzna miała szansę na utworzenie niepodległego organizmu państwowego? Jak się wydaje, możliwości takie były bardzo ograniczone. Wynikało to z kilku powodów. Przede wszystkim byłoby to państwo całkiem nowe, bez wcześniejszych tradycji, bo przecież trudno byłoby Kozakom powoływać się na Ruś Halicko-Włodzimierską czy Wielkie Księstwo Kijowskie. Co prawda możliwa jest akceptacja przez sąsiadów powstania nowego organizmu - przez podział starego, ale większą sympatią cieszą się te powstające państwa, które tylko na pewien czas utraciły swój byt. Niepodległa Kozaczyzna gwałtownie burzyła układ sił w tej części Europy. Nie było to na rękę ani Rzeczypospolitej, ani Moskwie, ani Turcji, nie mówiąc już o księstwach naddunajskich. Owszem Moskwa, Turcja czy Siedmiogród chętnie brały lub chciały brać Kozaków pod swą protekcję lub panowanie, ale chętnych do zaakceptowania państwa kozackiego raczej brakowało. Był jeszcze jeden czynnik działający na niekorzyść 
Hetmanatu. Otóż Chmielnicki i jego zwolennicy byli przez sąsiadów postrzegani jako zbuntowani poddani polskiego monarchy. Owszem, można im było udzielić jakiejś pomocy, bo to osłabiało państwo polsko-litewskie, ale traktowanie Chmielnickiego jak równego monarchom nie wchodziło w rachubę. Traktat w Radnot stwarzał dla Kozaków szansę incydentalną. Tak Szwecja, której podbój Polski wyraźnie nie wychodził, jak i Siedmiogród, który czuł się za słaby, aby zawojować swoją część Królestwa, potrzebowali na gwałt sojusznika. To samo można także powiedzieć w tym momencie o elektorze Fryderyku Wilhelmie. Szansę Kozacy stracili, bo ofiara zaborczych planów okazała się za silna, a w dodatku sąsiedzi, i to ci najpotężniejsi, postanowili jej pomóc.

Reasumując rozważania, warto podnieść kwestię okoliczności, w jakich dochodziło do przezwyciężania kryzysów państwowości połączonych z krótszym lub dłuższym okresem braku organizmu państwowego. Można też pokusić się o znalezienie warunków uniemożliwiających powstawanie nowych państw. Zasadniczy czynnik niezbędny do odrodzenia się organizmu państwowego, przezwyciężenia kryzysu i powstania zupełnie nowego organizmu państwowego to dążenie danej społeczności, lub jej znaczącej części, do uzyskania suwerenności na danym obszarze, stanowiącym dawny lub niedawny teren własnej państwowości. Dążenie to musi być na tyle silne, aby skłonić część lub całość społeczeństwa stanowego nie tylko do buntu, ale także do długotrwałej walki z silniejszym niekiedy przeciwnikiem. Taki warunek spełniły wszystkie w zasadzie stany w Rzeczypospolitej Obojga Narodów, poczynając od jesieni 1655 r. Podobnie określić można postawę Portugalczyków i Kozaków zaporoskich, choć ci ostatni skłaniali się także do koncepcji oddawania się pod protekcję różnych potęg, w tym i Rzeczypospolitej. Warunku tego nie spełniali natomiast Katalończycy w latach 1640-1652, którzy panowanie hiszpańskie zamienili na panowanie francuskie.

Drugi nieodzowny czynnik to sprzyjający układ międzynarodowy. Jak się wydaje, bardzo korzystna jest co najmniej życzliwa postawa jednego z mocarstw bądź sąsiadów. W przypadku Portugalii była to przede wszystkim Francja, w przypadku państwa polsko-litewskiego - pomoc Tatarów krymskich przy życzliwości Turcji. W trakcie walk ze Szwedami zmieniali swoją wrogą postawę niektórzy sąsiedzi, jak Moskwa i Brandenburgia, inni, niebędący nigdy wrogo nastawieni, jak Cesarstwo i Dania, włączali się do koalicji antyszwedzkiej. Takiej koniunktury nie mieli właściwie Kozacy, poza okresem związanym z traktatem w Radnot. Gdyby Polskę udało się wówczas pokonać, być może powstałoby na jego gruzach także państwo kozackie. Ofiara okazała się jednak zbyt żywotna i Kozacy stracili swoją unikalną szansę na niepodległość. Warto podkreślić, że istnieje 
jeszcze jeden czynnik. Otóż broniące się państwo lub społeczność walcząca o jego odzyskanie musi wykazać taką determinację, że niektórym sąsiadom opłaca się udzielić mu większej lub mniejszej pomocy.

\section{Streszczenie}

Rzeczpospolita Obojga Narodów przeszła w połowie XVII stulecia głęboki, wielostronny kryzys. Miał on swoje aspekty demograficzne, gospodarcze, polityczne i militarne. Doprowadził najpierw do rozpadu państwa w 1655 r., a następnie do próby jego podziału w grudniu 1656, określanej często jako próba pierwszego rozbioru Polski. Czynniki, jakie wówczas sprzyjały kryzysowi i rozpadowi państwa to: losowe - śmierć króla Władysława IV na początku powstania Chmielnickiego; zewnętrzne: zaatakowanie Rzeczypospolitej przez Moskwę, Szwecję, Siedmiogród, Brandenburgię i początkowo przez Tatarów; wewnętrzne: dążenia Kozaków zaporoskich, postawa części magnaterii, kryzys moralny przejawiający się w braku woli walki w pierwszej połowie $1655 \mathrm{r}$. Czynniki pozwalające na przełamie kryzysu państwa to: wciąż duży potencjał państwa, tak militarny, jak i gospodarczy. Poza tym dużą rolę odegrały okoliczności wewnętrzne: przezwyciężenie załamania moralnego i powrót chęci walki z wrogami, zdobycie się na nowe rozwiązania ustrojowe (krótkotrwałe: konwokacja senatu i szlachty zamiast sejmu, elekcja vivente rege cara, wyprawy dymowe ze wszystkich dóbr ziemskich, pogłówne) oraz zewnętrzne, czyli postawa sąsiadów niegodzących się z rozbiorem Rzeczypospolitej Obojga Narodów, a więc Tatarów, Habsburgów, Danii i w pewnym okresie także Moskwy.

Czy w okresie wczesnonowożytnym mieliśmy do czynienia z przypadkami załamania państwowości i jej odbudowy? W długim okresie załamanie dotyczyło Węgier pod panowaniem habsburskim. Jeśli chodzi o ponowne odrodzenie się państwowości, to można wymienić Portugalię, która uzyskała suwerenność w 1640 r. pod berłem narodowej dynastii Bragança. Podjęto także nieudaną próbę reaktywacji Królestwa Aragonii w 1640 r. (walki zbrojne trwały przez 12 lat).

\section{The Crisis, Collapse, and Revival of the Commonwealth during the Second Northern War (1655-1660)}

In the mid-seventeenth century, the Polish-Lithuanian Commonwealth was hit by a severe and multi-dimensional crisis, which had demographic, economic, political and military aspects. The crisis led, first, to the collapse of the state in 1655, and then to the attempt at its division in December 1656, often called an attempt at its first partition. There were several factors that precipitated the crisis and the downfall of the state: those of fate, such as King Władysław IV's death in the early stage of the Khmelnytsky uprising in 1648; external ones: the attack on the Commonwealth by Moscow, Sweden, Transylvania, Brandenburg, and - initially - the Tatars; internal ones: the Zaporozhian Cossacks, the attitude of part 
of the magnates, a moral crisis manifesting itself in the lack of the will to fight in the first half of 1655. The factors that made it possible to ease the crisis were the still considerable potential of the state, both military and economic. Besides this, a significant role was played by internal aspects: the overcoming of moral breakdown and regaining of the will to fight against enemies, the introduction of some changes into the political system (albeit short-lived: a convocation of the Senate and nobility instead of the Sejm, the vivente rege election of the tsar as successor, special summary military units, so-called wyprawy dymowe, from all landed estates, head tax, etc.), and external ones, such as the attitude of neighbours who did not consent to the partition of the Polish-Lithuanian Commonwealth: the Tatars, the Habsburgs, Denmark, and for some time even Moscow.

Were there cases of collapsed statehood in the early modern period and its reconstruction? In the long-term perspective, it was Hungary that suffered the decay of the state under the Habsburgs. As to the revival of the statehood, Portugal could be mentioned, which regained its independence from Spain in 1640 under the national dynasty of Bragança. There was also a failed attempt at reactivation of the Kingdom of Aragon in 1640 (the fight continued for twelve years).

Translated by Grażyna Waluga

\section{Bibliografia}

Czapliński Władysław, Rola magnaterii i szlachty w pierwszych latach wojny szwedzkiej, w: Polska w okresie drugiej wojny pótnocnej 1655-1660, t. 1: Rozprawy, red. Adam Przyboś, Kazimierz Lepszy, PWN, Warszawa 1957.

Dąbrowski Janusz S., Polskie elity wobec Szwecji w przededniu potopu, w: Z dziejów stosunków Rzeczypospolitej Obojga Narodów ze Szwecja w XVII wieku, red. Mirosław Nagielski, DiG, Warszawa 2007.

Frost Robert I., After the Deluge. Poland-Lithuania and the Second Northern War 16551660, Cambridge University Press, Cambridge 1993.

Frost Robert I., The Northern Wars 1558-1721, Longman, Harlow-London 2000.

Herbst Stanisław, Wojna obronna 1655-1660, w: Polska w okresie drugiej wojny pótnocnej 1655-1660, t. 2: Rozprawy, red. Adam Przyboś, Kazimierz Lepszy, PWN, Warszawa 1957.

Kersten Adam, Hieronim Radziejowski. Studium władzy i opozycji, PIW, Warszawa 1988. Konopczyński Władysław, Dzieje Polski nowożytnej, t. 2: 1648-1795, Gebethner i Wolff, Warszawa 1936.

Kossarzecki Krzysztof, Szlachta litewska wobec panowania szwedzkiego i moskiewskiego, w: Z dziejów stosunków Rzeczypospolitej Obojga Narodów ze Szwecją w XVII wieku, red. Mirosław Nagielski, DiG, Warszawa 2007.

Majewski Wiesław, Poddawanie się Szwedom w Koronie w 1655 roku, w: Z dziejów stosunków Rzeczypospolitej Obojga Narodów ze Szwecja w XVII wieku, red. Mirosław Nagielski, DiG, Warszawa 2007.

Miłkowski Tadeusz, Machcewicz Paweł, Historia Hiszpanii, Ossolineum, Wrocław 1998. 
Nagielski Mirosław, Koncepcje prowadzenia działań przeciwko Szwedom w dobie potopu, w: Z dziejów stosunków Rzeczypospolitej Obojga Narodów ze Szwecja w XVII wieku, red. Mirosław Nagielski, DiG, Warszawa 2007.

Nowak Tadeusz, Geneza agresji szwedzkiej, w: Polska w okresie drugiej wojny pótnocnej 1655-1660, t. 1: Rozprawy, red. Adam Przyboś, Kazimierz Lepszy, PWN, Warszawa 1957.

Ochman-Staniszewska Stefania, Staniszewski Zdzisław, Sejm Rzeczypospolitej za panowania Jana Kazimierza Wazy. Prawo - doktryna - praktyka, t. 1, Wydawnictwo Uniwersytetu Wrocławskiego, Wrocław 2000, s. 233-234.

Oliveira Marques Antonio Henrique de, Historia Portugalii, t. 1: Do XVIII wieku, PWN, Warszawa 1987.

Opaliński Edward, Społeczeństwo szlacheckie wobec Rzeczypospolitej Obojga Narodów w okresie 1572-1668. Reakcja na spadek efektywności państwa, w: My i oni. Społeczeństwo nowożytnej Rzeczypospolitej wobec państwa, red. Wojciech Kriegseisen, IH PAN, Warszawa 2016.

Rachuba Andrzej, Kiaupienė Jūratė, Kiaupa Zigmantas, Historia Litwy. Dwugłos polsko-litewski, DiG, Warszawa 2008.

Rachuba Andrzej, Paweł Sapieha wobec Szwecji i Jana Kazimierza (IX 1655 - II 1656), „Acta Baltico-Slavica” 11, 1977, s. 81-107.

Radziwiłł Bogusław, Autobiografia, wstęp i oprac. Tadeusz Wasilewski, PIW, Warszawa 1979.

Stangreciuk Mariusz, Traktat w Radnot (6 grudnia 1656) jako pierwsza próba rozbioru ziem Rzeczypospolitej. Przyczyny, realizacja, w: Z dziejów stosunków Rzeczypospolitej Obojga Narodów ze Szwecją w XVII wieku, red. Mirosław Nagielski, DiG, Warszawa 2007.

Wójcik Zbigniew, Dzieje Rosji. 1533-1801, PWN, Warszawa 1971.

Wójcik Zbigniew, Polska i Rosja wobec wspólnego niebezpieczeństwa szwedzkiego w okresie wojny północnej 1655-1660, w: Polska w okresie drugiej wojny północnej 1655-1660, t. 1: Rozprawy, red. Adam Przyboś, Kazimierz Lepszy, PWN, Warszawa 1957.

Żojdź Karol, Traktat z Radnot i udział Bogusława Radziwiłła w planach podziału Rzeczypospolitej, „Studia Historyczno-Wojskowe” 5, 2015, s. 176-194.

Чухліб Тарас, Концеепція полівасалітетної підлеглості Б. Хмельницъкого та українсько-російські взаємовідносини середини XVII cm., w: Україна та Росія. Проблеми політичних і соціокультурних відносин. Збірник наукових працьь, red. Валерій А. Смолій et al., Інститут історії України НАН України, Київ 2003, s. 146-173.

Biogram: Edward Opaliński, prof. dr hab., pracownik Instytutu Historii PAN w Warszawie oraz Uniwersytetu Jana Kochanowskiego w Kielcach, Filia w Piotrkowie Trybunalskim. Zainteresowania: elity władzy, parlamentaryzm, kultura polityczna Rzeczypospolitej i Rzeszy (Brandenburgia, Meklemburgia) w XVI-XVII w.; kontakt: e.opalinski@gmail.com. 